\title{
Changes in Body Water Distribution During the First Two Weeks of Life
}

\author{
JOHN C. MACLAURIN \\ From the University Department of Child Health, the Royal Hospital for Sick Children, \\ and the Royal Maternity Hospital, Glasgow
}

Increasing interest in the past 25 years in problems of neonatal physiology and pathology has led to much basic work on the normal newborn, both fullterm and premature. Standards of normality involving many parameters have been evaluated, and it is noteworthy that many of these determinations show wide subject-to-subject variation.

Not least among measurements showing this wide variation are determinations of the body-water compartments, both for full-term infants (Flexner, Wilde, Proctor, Cowie, Vosburgh, and Hellman, 1947; Friis-Hansen, Holiday, Stapleton, and Wallace, 1951; Fink and Cheek, 1960; Hanna, 1960) and for prematures (Clapp, Butterfield, and O'Brien, 1962; Smull, 1958).

This study has been undertaken for two reasons. First, it appears that some premature infants, accepted in the literature as 'normal', may in fact become abnormal in this respect, because of an inability, due to immaturity, to control their own body water readily. Any such variation would be móst likely to occur some days after birth. Secondly, the first week of life is a period of enormous change, and it would be surprising if water distribution did not play a major part in these changes. Shifts of fluid between the intravascular and the interstitial compartments have been shown to occur during the first 12 hours of life (Clark and Gairdner, 1960; Usher, Shephard, and Lind, 1963). The possibility of shifts occurring between the intracellular and the extracellular spaces has not, however, been adequately investigated. A pointer towards such a possibility lies in the clinical observation that an infant with little or no demonstrable oedema at birth may become oedematous during the first 24 hours (Sutherland, Oppé, Lucey, and Smith, 1959). During this period weight loss will certainly have occurred, though the infant may well have had no fluid intake.

Received November 25, 1965.

\section{Case Material and Methods.}

The subjects of this study were 46 apparently healthy infants born by spontaneous vertex delivery in the Royal Maternity Hospital, Glasgow. No standardization of time interval regarding clamping of the cord was introduced. The birth weights varied from $1.62 \mathrm{~kg}$. to $3.65 \mathrm{~kg}$. and the ages from 4 hours to 13 days. 4 of the infants were clinically mildly oedematous at the time of the determination. 39 were examined during the first 6 days of life and form a special part of the investigation.

In each subject the weight was recorded daily for the first week or until body water determination was carried out, whichever period was the longer. In 2 infants oral fluids were started at 12 hours; in the rest, at 24 hours. Water was offered twice, 4 hours apart, the quantities being decided by the infants. 15 or $30 \mathrm{ml}$. half-cream milk was then offered every 3 or 4 hours according to the infant's size, with increments dependent on demand.

Forty-six determinations were made of extracellular space (thiocyanate) and blood volume (Evans Blue); total body water (antipyrine) was estimated in $\mathbf{3 0}$ of the same infants. The indicator substances were injected and standardized by the method described by Jegier, MacLaurin, Blankenship, and Lind (1964). No untoward reactions were noted in the infants.

A venous sample $(5 \mathrm{ml}$.) was withdrawn 10 minutes after injection for Evans Blue, haematocrit, and, in 34 subjects, $\mathrm{Hb}$ determination. Capillary samples were withdrawn at 2,3 , and 5 hours. The concentration of antipyrine was estimated in each of these and the 2-hour sample was used also for the single determination of thiocyanate required. All samples were withdrawn into tubes containing dried heparin.

Evans Blue was extracted using the method of Bedwell, Patterson, and Swale (1955). The original method used $4 \mathrm{ml}$. plasma, but with a slightly higher concentration of dye it was found by extraction experiments that $2 \mathrm{ml}$. plasma could be used without significant loss of accuracy. Recovery in 10 such experiments averaged $98 \cdot 6 \%( \pm$ S.D. 1.4 $)$.

Venous haematocrit was read on a micro-haematocrit centrifuge (Hawksley) spinning at 15,000 r.p.m. for 5 minutes. No correction was made for trapped plasma. Total body haematocrit was calculated using the factor $0 \cdot 87$, as suggested by Mollison, Veall, and Cutbush 
TABLE I

Data (mean values, \pm S.E.) for 46 Subjects Divided into 3 Groups by Age

\begin{tabular}{|c|c|c|c|c|c|c|c|c|}
\hline Age & $\begin{array}{c}\text { No.* } \\
\text { of } \\
\text { Subjects }\end{array}$ & $\begin{array}{c}\text { Weight } \\
\text { (kg.) }\end{array}$ & $\begin{array}{c}\text { Total Body } \\
\text { Water } \\
(\mathrm{ml} / \mathrm{kg} .)\end{array}$ & $\begin{array}{c}\text { Extracellular } \\
\text { Water } \\
\text { (ml./kg.) }\end{array}$ & $\begin{array}{c}\text { Intracellular } \\
\text { Water } \\
\text { (ml./kg.) }\end{array}$ & $\begin{array}{c}\text { Plasma } \\
\text { Volume } \\
(\mathrm{ml} . / \mathrm{kg} .)\end{array}$ & $\begin{array}{c}\text { Total Body } \\
\text { Hct. }(\%)\end{array}$ & $\mathrm{Hb}(\mathrm{g} . / 100 \mathrm{ml})$. \\
\hline $\begin{array}{c}4 \mathrm{hr} .-3 \mathrm{dy} \\
4-5 \mathrm{dy} \\
6-13 \mathrm{dy}\end{array}$ & $\begin{array}{r}26 \\
13 \\
7\end{array}$ & $\begin{array}{l}2 \cdot 46 \\
2 \cdot 00 \\
2 \cdot 33\end{array}$ & $\begin{array}{l}715 \pm 10 \cdot 3 \\
719 \pm 20 \cdot 8 \\
692\end{array}$ & $\begin{array}{l}360 \pm 7 \cdot 0 \\
358 \pm 7 \cdot 5 \\
359\end{array}$ & $\begin{array}{l}356 \pm 10 \cdot 1 \\
366 \pm 18 \cdot 5 \\
339\end{array}$ & $\begin{array}{l}45 \cdot 1 \pm 1 \cdot 32 \\
48 \cdot 5 \pm 1 \cdot 64 \\
52 \cdot 2\end{array}$ & $\begin{array}{l}46 \cdot 6 \pm 1 \cdot 31 \\
48 \cdot 7 \pm 0 \cdot 97 \\
47 \cdot 1\end{array}$ & $\begin{array}{l}16.8 \pm 0.42 \\
17.5 \pm 1.17 \\
16 \cdot 7\end{array}$ \\
\hline Total & 46 & $2 \cdot 31$ & $713 \pm 10.4$ & $359 \pm 4 \cdot 8$ & $356 \pm 10 \cdot 1$ & $47 \cdot 2 \pm 1 \cdot 03$ & $47 \cdot 3 \pm 0 \cdot 85$ & $17 \cdot 0 \pm 0 \cdot 28$ \\
\hline
\end{tabular}

* The number of determinations of total body water and intracellular water in the three groups is 15,10 , and 5 , respectively.

(1950). Plasma water was estimated as (Evans Blue space) $\times 0.93$ (Puranen, Harri, and Hallman, 1957).

Determination of haemoglobin was by the cyanmethaemoglobin method.

Thiocyanate space was estimated using the method of Bowler (1944). Using 1/5 quantities throughout, and thus $0.2 \mathrm{ml}$. of plasma, no significant loss of reproducibility was encountered. Protein-free supernatant fluid was obtained by centrifugation instead of filtration. Concentration in plasma water for both this and antipyrine was derived using the factor 0.93. Duplicate estimation of one plasma sample only was necessary in view of the known slow rate of excretion of this ion-less than $1 \%$ per hour. This was confirmed in 3 infants of this series. No correction was made for Donnan equilibrium, intracellular migration of thiocyanate ion, or protein-binding of the ion in plasma.

Determination of antipyrine space was by the micromethod of Mendelsohn and Levin (1960). The concentrations in plasma water at 2,3 , and 5 hours were determined in duplicate and plotted on semi-logarithmic paper, the theoretical concentration at zero time being obtained by extrapolation in the usual way.

The volume of intracellular water was derived by subtraction of thiocyanate space from the antipyrine

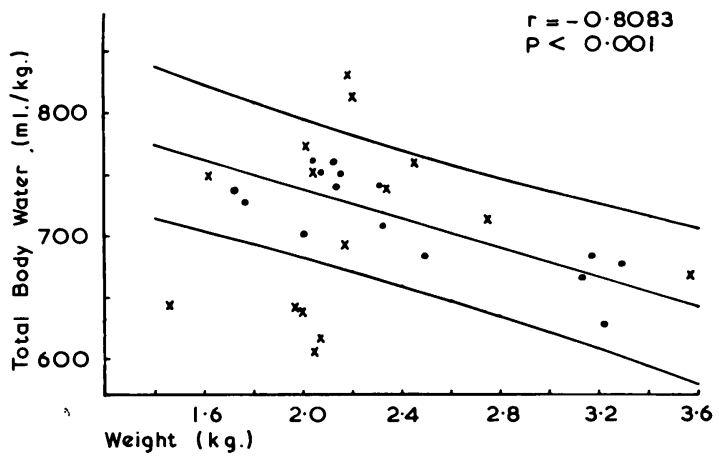

FIG. 1.-The regression of total body water (ml./kg.) on body weight. Filled circles represent infants less than 72 hours old, the crosses infants above this age. The linear regression line with its $95 \%$ confidence limits applies to the younger group only. space, and of the interstitial compartment by subtraction of plasma water from the thiocyanate space.

All the biochemical determinations were done by the author.

\section{Results}

The data obtained for body weight, total water, thiocyanate space, intracellular water, plasma volume, haematocrit, and haemoglobin determinations are shown in Table I.

Total body water expressed in ml./kg. body weight has been plotted against weight in Fig. 1. The infants have been divided into those of 3 days and less (closed circles) and those of more than 3 days old (crosses). The linear regression line with its $95 \%$ confidence limits refers only to the 15 infants aged 3 days and less. These are negatively correlated $(r=-0.8083 ; p<0.001)$. Of the infants older than 3 days, all those heavier than $2 \cdot 20 \mathrm{~kg}$. at the time of estimation show results within the same confidence limits. Of the 10 infants below this weight, however, 7 lie well outside these limits.

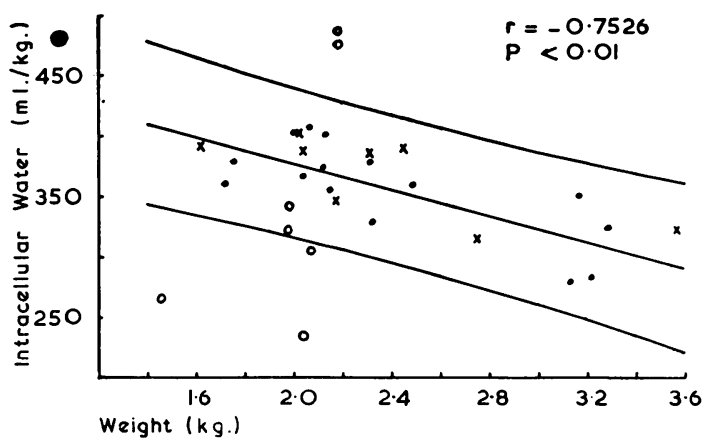

FIG. 2.-The regression of intracellular water ( $\mathrm{ml} . / \mathrm{kg}$.$) on$ body weight. Filled circles and crosses as in Fig. 1. Open circles represent the 7 infants with 'abnormal' total body water (see Fig. 1). 
The results for intracellular water against weight shown in Fig. 2 indicate a similar significant negative correlation $(r=-0.7526, p<0.01)$ to total body water. The instability of total body water in the smaller infants over 3 days old is shown to be mainly associated with alterations in this compartment, 5 of the same 7 infants (open circles) lying outside the $95 \%$ confidence limits.

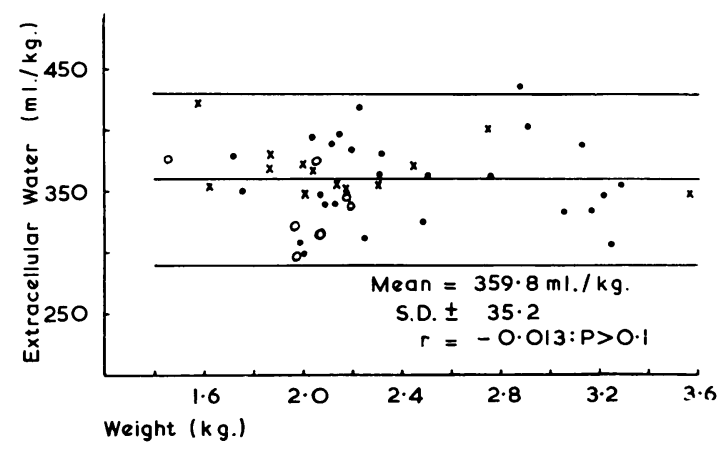

FIG. 3.-The regression of thiocyanate space (ECW) on body weight. Mean \pm two standard deviations.

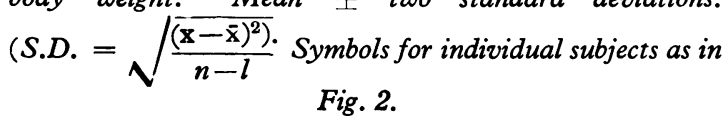

The same treatment of the thiocyanate spaces (Fig. 3) reveals a different relation. Here the proportion of extracellular water is constant $(r=$ $0.0106 ; p>0 \cdot 1)$. Within these limits it appears that after three days the extracellular space is more effectively maintained than the intracellular. A very similar relationship applies to plasma volume (Fig. 4).

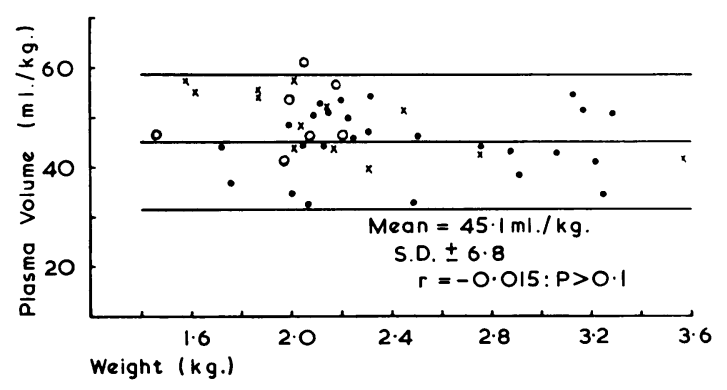

FIG. 4.-The regression of plasma volume on body weight. Mean \pm two standard deviations. Symbols for individual subjects as in Fig. 2.
From the above evidence it seemed reasonable to conclude that certain of the subjects should be considered to have an abnormal proportion of total body water. These infants have, therefore, been omitted from the remainder of the investigation. Following the same argument, all values for thiocyanate space, and all save one of the results for plasma volume, may be considered to be normal and have, therefore, been used in the second part of the investigation.

It was clear in this series that the variability of the proportion of extracellular water to body weight was relatively great; the factor of alteration with time was therefore analysed. Values for extracellular water during the first 6 days of life were available in 39 infants, the number of observations per day averaging $6 \cdot 5$ (range $5-8$ ). The mean ( \pm S.E. ${ }^{\star}$ ) for each day is seen plotted in Fig. 5; the connecting line is parabolic in shape, with an immediate rise from the first to the second day of life. The maximum occurs on the fourth day, with return towards the birth values by the sixth day.

Using the method of least squares, a calculated parabola was fitted to these results. The appropriate regression equation is

$$
Y=292 \cdot 32+47 \cdot 204 x \times 6 \cdot 359 x^{2},
$$

where $Y=$ extracellular water (ml./kg.), and $x=$ day of life within the period under study (1-6). Analysis of variance indicates that the parabolic component of the above equation is highly significant $(F=9.90 ; p<0.01)$. The calculated parabola has a maximum at $3 \cdot 7$ days, and the closeness of fit to the observed results is seen in Fig. 5.

During the first 6 days of life, important changes are taking place in body weight. It does not necessarily follow that the above changes in proportional extracellular water reflect absolute changes in this compartment. Serial alteration of the weights of all 39 infants (mean \pm S.E.) are indicated at the top of Fig. 6 . If it is assumed that water distribution will behave in a roughly similar fashion during this period irrespective of birthweight, then it becomes justifiable to apply the curve derived in Fig. 5 to these changes in weight. The results of this are indicated in Table II, and suggest that a significant absolute rise in extracellular water does in fact occur during the first 4 days. Since only one of the infants measured during the second day of life had been given oral fluids, it follows that the increase at this time can only have been derived by transfer of water from the intracellular space.

$$
\star \text { Standard error }=\sqrt{\frac{\sum(x-\bar{x})^{2}}{n(n-1)}} .
$$




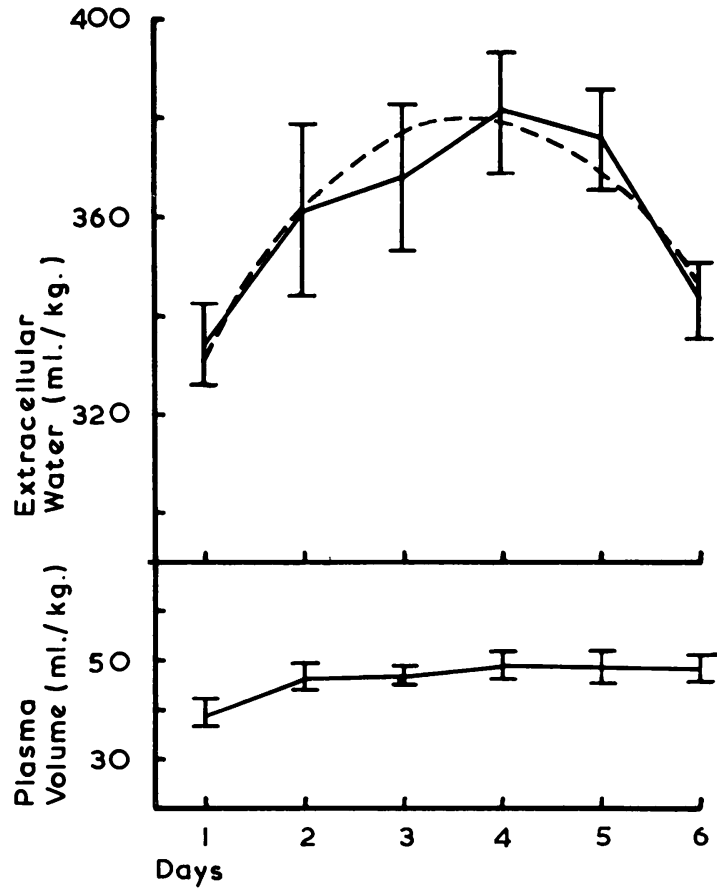

Fig. 5.-Daily values (ml./kg.) for extracellular and plasma volumes (mean 士 S.E.) in 39 subjects. Broken line represents calculated parabolic regression line for extracellular water (see text).

These absolute changes in extracellular water are depicted in Fig. 6. Subtraction of the value for each day from the mean measured weight gives a value that should correspond to the sum of intracellular water and 'solids'. Similar curves could not be derived for total body water or intracellular water, since after elimination of a number of the cases for the reasons previously discussed, the scatter of the remaining results was such that they did not correspond to a calculated curve to a

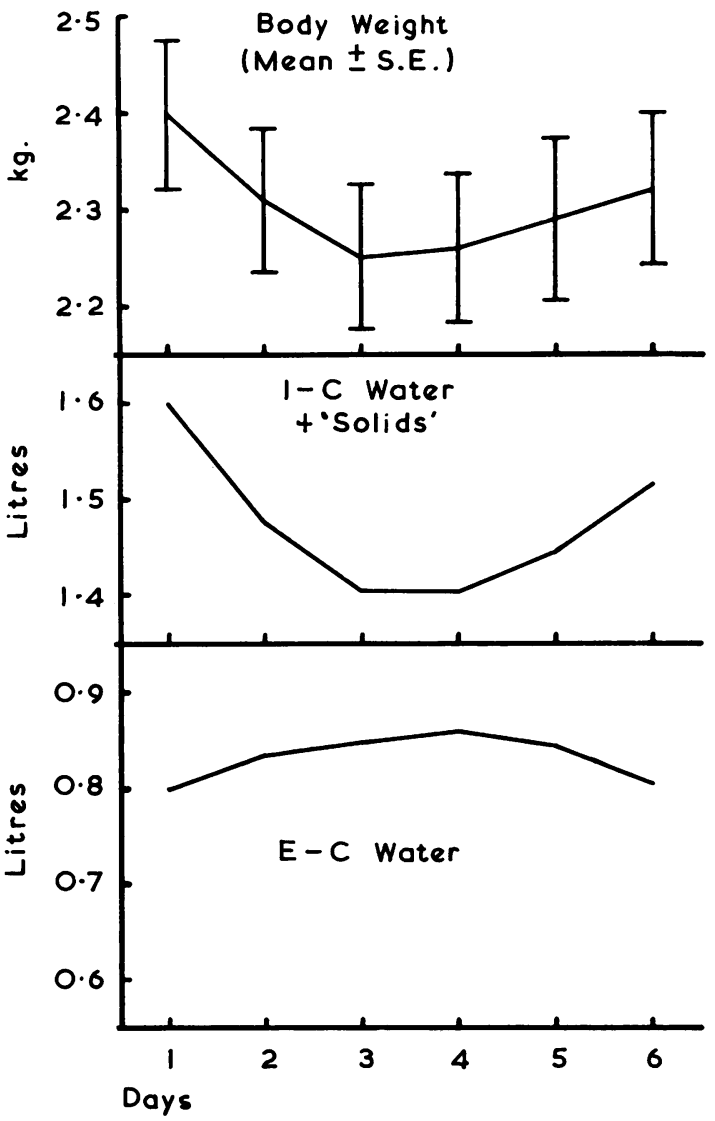

FIG. 6.-Upper graph indicates observed changes in body weights (mean $\pm S . E$.). Lower graph represents changes in mean absolute extracellular water (see text for derivation). Values for 'intracellular water + solids' obtained by subtraction of extracellular water from mean weight.

statistically significant degree. Osmotic changes affecting red cells were investigated using the MCHC, the changes in the daily readings (mean \pm

TABLE II

Changes in Extracellular Water-39 Subjects

\begin{tabular}{|c|c|c|c|c|c|}
\hline Day of Life & $\begin{array}{c}\text { No. of } \\
\text { Observations }\end{array}$ & $\begin{array}{l}\text { Observed Extracellular } \\
\text { Water Mean } \pm \text { S.E. } \\
\text { (ml./kg.) }\end{array}$ & $\begin{array}{l}\text { Calculated Mean } \\
\text { Extracellular Water } \\
\text { from } \star \text { Regression } \\
\text { Eqn. (ml./kg.) }\end{array}$ & $\begin{array}{l}\text { Body Weight (g.) } \\
\text { Mean } \pm \text { S.E. }\end{array}$ & $\begin{array}{c}\text { Calculated Mean } \\
\text { Absolute } \\
\text { Extracellular Water } \\
\text { (ml.) }\end{array}$ \\
\hline $\begin{array}{l}1 \\
2 \\
3 \\
4 \\
5 \\
6\end{array}$ & $\begin{array}{l}8 \\
6 \\
5 \\
7 \\
6 \\
7\end{array}$ & $\begin{array}{l}334 \pm 8 \\
362 \pm 17 \\
368 \pm 15 \\
382 \pm 12 \\
376 \pm 10 \\
343 \pm 8\end{array}$ & $\begin{array}{l}333 \\
361 \\
377 \\
379 \\
369 \\
347\end{array}$ & $\begin{array}{l}2,400 \pm 76 \\
2,310 \pm 73 \\
2,250 \pm 74 \\
2,260 \pm 76 \\
2,290 \pm 82 \\
2,320 \pm 78\end{array}$ & $\begin{array}{l}799 \\
834 \\
848 \\
857 \\
845 \\
805\end{array}$ \\
\hline
\end{tabular}

$\star$ See text. 


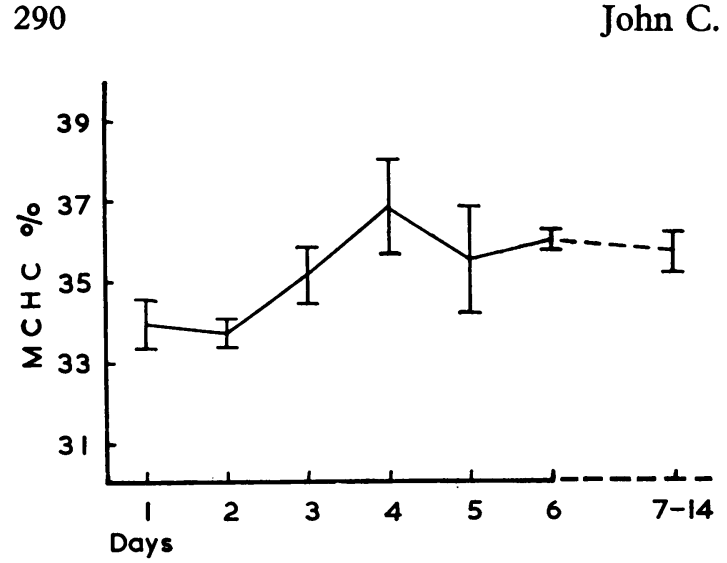

FIG. 7.-Changes in mean corpuscular haemoglobin concentration (mean \pm S.E.).

S.E.) being indicated in Fig. 7. The general increase followed by decrease corresponds roughly with the changes in extracellular water shown in Fig. 5.

The daily changes in plasma volume, expressed in ml./kg. (mean \pm S.E.), are also shown in Fig. 5. A slight rise between days 1 and 2 occurs, corresponding to the increase in total extracellular water during this period. Thereafter the mean values remain constant, not sharing in the decrease of total extracellular water between days 4 and 6 . When the ratio $\frac{\text { Plasma water }}{\text { Interstitial water }}$ is plotted against time, a distinct profile emerges (Fig. 8). An increase in the ratio from day 1 to day 2 is followed by almost exact constancy until day 5, after which the ratio starts to increase towards the values of later infancy and childhood. This ultimate increase is due almost entirely to relative decrease of the interstitial volume, the plasma volume when expressed in $\mathrm{ml} . / \mathrm{kg}$. remaining fairly constant.

\section{Discussion}

It is by no means unexpected that the control of the volume of body water is apparently relatively unstable in the smaller infants of this series. That this instability should affect mainly the intracellular compartment is of some interest.

The control of intracellular fluid volume and solute concentration depends on the fact that under normal circumstances the total solute concentration of intracellular fluid is the same as that of extracellular fluid (Maffly and Leaf, 1958). Thus changes in the latter result in passive osmotic shift of water with alteration of intracellular volume.

Extracellular fluid volume on the other hand is controlled by at least two mechanisms. First, the presence of direct volume receptors controlling the extracellular fluid is now hardly in doubt (Smith, 1957). Secondly, the concentration of extracellular solute determines the release of $\mathrm{ADH}$ from the pituitary and hence the volume of water reabsorbed by the renal tubules (Verney, 1947). Renal function in the newborn differs from that of the adult kidney in certain important respects. It is characterized by low values for glomerular filtration rate (Barnett, Hare, McNamara, and Hare, 1948), excretion of solutes (McCance and Young, 1941), and maximal concentrating power (Poláček, Vocel, Neugebauerová, Sebková, and Věchetová, 1965), especially in premature infants. It would be reasonable to suppose, therefore, that renal inefficiency of this kind would tend to result primarily in alterations of extracellular solute concentration and hence in changes in intracellular volume.

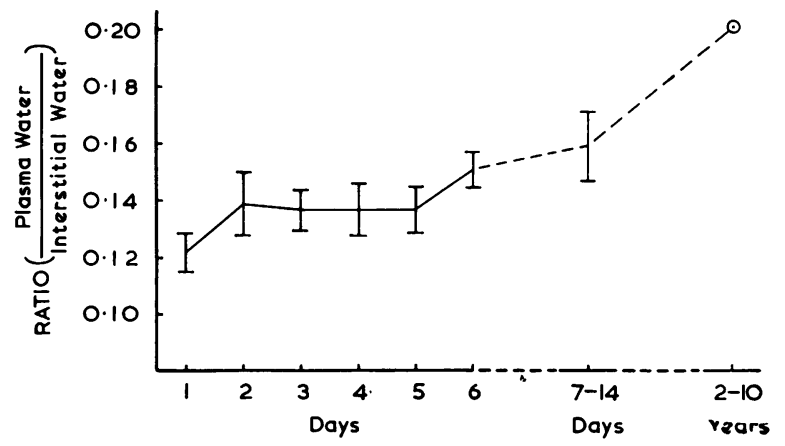

Fig. 8.-Changes in the ratio $\frac{\text { plasma water }}{\text { interstitial water }}$ (mean \pm S.E.). The value for older children is taken from the mean of 20 children of age range 2-10 years (author's data). 


\section{Changes in Body Water Distribution During the First Two Weeks of Life}

During the first 48 hours of life, the combination of a degree of fluid deprivation with insensible loss puts a demand for urinary concentration on the kidneys, which they may well be unable to meet. Consequently there is a tendency for the serum sodium to rise (O'Brien, Hansen, and Smith, 1954). This must lead to osmotic transfer of water from the intracellular to the extracellular space, as the results of the present study suggest. It would be interesting to know if such a mechanism could prolong the presence of oedema present from birth or indeed play some part in its genesis. A further factor may be the release of intracellular water by the katabolic processes demonstrated during the first few days of life by the study of Nicolopoulos and Smith (1961).

A degree of intracellular dehydration must occur temporarily in this way, and it is interesting to derive some measure of support for these findings from the changing values of the MCHC. Under the influence of osmotic change, the red cells have long been known to act as simple osmometers (Streeten and Thorn, 1957). The correlation of cell hydration with $\mathrm{MCHC}$ is of course negative, and hence the increase in MCHC is associated with a decreasing intracellular volume, as water is transferred from there to the extracellular space.

Amongst others, Usher et al. (1963) have demonstrated a rise in plasma volume during the first 24 hours, ascribing this to local increase in circulation which affects perhaps the gastro-intestinal tract. The present findings suggest that at least part of the increase in plasma volume is due to the general expansion of extracellular volume taking place at this time.

\section{Summary}

Measurements of total body water, extracellular volume, and plasma volume carried out on 46 newborn full-term and premature infants have yielded the following information

Premature infants in the first few days of life showed a marked instability of the control of total body water.

When present, this instability affected primarily the intracellular volume.

A day-to-day study indicated that during the first 3 days the extracellular volume rose. The evidence suggested that this increase was largely due to transfer of water from the intracellular space.

These findings were to some extent confirmed by changes observed in $\mathrm{MCHC}$.

It is suggested that the early expansion of extracellular volume may partly account for a coincident rise in the plasma volume.

I am indebted to Professor J. H. Hutchison for access to patients and helpful criticism, to Dr. H. E. C. Wilson,
Department of Biochemistry, Royal Hospital for Sick Children, for laboratory facilities and encouragement, to Dr. R. A. Robb of the Department of Mathematics, University of Glasgow, for advice regarding the statistical handling of the material, and to the nursing staff, Mrs. M. McLay in particular, of the Paediatric Unit, Royal Maternity Hospital, Glasgow, for assistance and forbearance.

Part of the expenses of this project was defrayed by a grant from the Rankin Research Fund of the University of Glasgow.

\section{REFERENCES}

Barnett, H. L., Hare, K., McNamara, H., and Hare, R. (1948). Measurement of glomerular filtration rate in premature infants. f. clin. Invest., 27, 691 .

Bedwell, G. A., Patterson, J., and Swale, J. (1955). The estimation of Evans blue in plasma. F. clin. Path., 8, 61 .

Bowler, R. G. (1944). The determination of thiocyanate in blood serum. Biochem. F., 38, 385.

Clapp, W. M., Butterfield, L. J., and O'Brien, D. (1962). Body water compartments in the premature infant, with special reference to the effects of the respiratory distress syndrome and of maternal diabetes and toxemia. Pediatrics, 29, 883.

Clark, A. C. L., and Gairdner, D. (1960). Postnatal plasma shift in premature infants. Arch. Dis. Childh., 35, 352.

Fink, C. W., and Cheek, D. B. (1960). The corrected bromide space (extracellular volume) in the newborn. Pediatrics, 26, 397.

Flexner, L. B., Wilde, W. S., Proctor, N. K., Cowie, D. B., Vosburgh, G. J., and Hellman, L. M. (1947). The estimation of extracellular and total body water in the newborn human infant with radioactive sodium and deuterium oxide. $\mathcal{F}$. Pediat., 30, 413.

Friis-Hansen, B. J., Holiday, M., Stapleton, T., and Wallace, W. M. (1951). Total body water in children. Pediatrics, 7, 321.

Hanna, F. (1960). Total body water and its distribution. Amer. $\mathcal{F}$. Dis. Child., 100, 723.

Jegier, W., MacLaurin, J. C., Blankenship, W., and Lind, J. (1964). Comparative study of blood volume estimation in the newborn infant using $\mathrm{I}^{131}$ labeled human serum albumin (IHSA) and T-1824. Scand. F. clin. Lab. Invest., 16, 125.

McCance, R. A., and Young, W. F. (1941). The secretion of urine by newborn infants. $\mathcal{F}$. Physiol. (Lond.), 99, 265.

Maffly, LeR. H., and Leaf, A. (1958). Water activity of mammalian tissues. Nature (Lond.), 182, 60.

Mendelsohn, D., and Levin, N. W. (1960). A colourimetric micromethod for the estimation of antipyrine in plasma or serum. S. Afr. F. med. Sci., 25, 13.

Mollison, P. L., Veall, N., and Cutbush, M. (1950). Red cell and plasma volume in newborn infants. Arch. Dis. Childh., 25, 242.

Nicolopoulos, D. A., and Smith, C. A. (1961). Metabolic aspects of idiopathic respiratory distress (hyaline membrane syndrome) in newborn infants. Pediatrics, 28, 206.

O'Brien, D., Hansen, J. D. L., and Smith, C. A. (1954). Effect of supersaturated atmospheres on insensible water loss in the newborn infant. ibid., 13, 126.

Poláček, E., Vocel, J., Neugebauerová, L., Sebková, M., and Věchetová, E. (1965). The osmotic concentrating ability in healthy infants and children. Arch. Dis. Childh., 40, 291.

Puranan, J., Harri, J., and Hallman, N. (1957). Titrimetric determination of the water content of plasma and erythrocytes. Ann. Paediat. Fenn., 3, 58.

Smith, H. W. (1957). Salt and water volume receptors. Amer. F. Med., 23, 623.

Smull, N. W. (1958). Total body water and bromide space determinations in premature infants. Amer. F. Dis. Child., 96, 494.

Streeten, D. H. P., and Thorn, G. W. (1957). Use of changes in the mean corpuscular hemoglobin concentration as an index of erythrocyte hydration. f. Lab. clin. Med., 49, 661.

Sutherland, J. M., Oppé, T. E., Lucey, J. F., and Smith, C. A. (1959). Leg volume changes observed in hyaline membrane disease. Amer. F. Dis. Child., 98, 24.

Usher, R., Shephard, M., and Lind, J. (1963). The blood volume of the newborn infant and placental transfusion. Acta paediat. (Uppsala), 52, 497.

Verney, E. B. (1947). The antidiuretic hormone and the factors which determine its release. Proc. roy. Soc. B, 135, 25. 